\title{
TRANSITION ECONOMY IN KOSOVO AFTER THE WAR
}

\author{
Nevruz Zogu, PhD \\ Artan Nimani, PhD \\ Shpetim Rezniqi, PhD
}

\begin{abstract}
This article analyses the development and consolidation of an illiberal (or shadow), economy and its connection to political projects in Serbia and Kosovo. Here, some comparative remarks are made over the form of economy and its political connections and implications. In spiteof methodological problems with sources being scarce or of varying quality, the phenomenon ofilliberal economy and its coupling with political projects is too important to be neglected byresearchers. To some extent 'soft sources' have been accepted here, where hard evidence is lacking. The article argues that the considerable consolidation of illiberal economies in Serbia and Kosovo(as elsewhere in the post-Yugoslav space) have been intimately connected to politics, politicalviolence and conflict in the region, and produced a transformation of wealth and resources. In thismanner the conflicts in the region can be analysed from the perspective of social transformation. Thelatter concept emphasises that the trajectory of social and political change is not necessarily linear,towards liberal democracy and market economy, which is implied in the concepts transition (wherethe end stage is assumed to be liberal democracy and market economy) or social breakdown (whichassumes a possible reconstruction to the norm of a harmonious state).
\end{abstract}

Keywords: Shadow economy, Illiberal economy, black economy, political economy of war, conflict, war-economy, parallel economy, war and state-building, drug-trade, Albanian mafia, organised crime, social transformation, Serbian-Albanian relations, Balkans, Yugoslavia, Serbia,Kosovo, ethnic conflict, terrorism

\section{Introduction}

The process of post-communist change in Eastern Europe has been approached from avariety of theoretical frameworks and assumptions. The most dominant and persistent isthe so-called 'transition view', which construes post-communist change as a struggle withthe heritage of authoritarian political systems and a planned economy towards the norm ofdemocracy and market liberalism, along the path of which various states are successful tovarying degrees. The term transition implies that one knows the direction or end state, anda problem here is that since democracy and a market economy are seen as the normativegoal, it also sets the direction and frame for interpreting the actual political, economic, andsocial process, thus mixing the normative and the empirical.

\section{The Re-stratification of Serbian Society}

In a period of some 15 years or so, under sanctions and war, Serbian society was transformed dramatically. The typical socialist structure gave way to class distinction andthe formation of a narrow stratum of very rich, while a great portion of society wasShadow Economy, War and State Building .

A large number of people were pushed into the grey or black sectors of theeconomy, or emigrated. Serbia also received an influx of between 600,000 and 1,000,000 refugees from Bosnia, Croatia and Kosovo, which due to their uncertain situation provided a further recruiting base for cheap labour in the black market sector. The deterioration in social standards and material life for the wider sections of society damaged all ethnic groups, including the (more than one-third) population which is not ethnic Serb(i.e. Kosovo excluded, the larger minorities include Albanians in south Serbia, Muslims orBosnjaks in Sandzak, Hungarians in Vojvodina, Croats in parts of Vojvodina, Romathroughout, and others). 


\section{Concluding Remarks}

The empirical picture provided in this article suggests a considerable expansion andconsolidation of illiberal forms of economy in Serbia and Kosovo through the 1990s, as integral to political projects. As an empirical note, rather than conclusion, it is estimated that the grey economy in Serbia has been reduced from some $80 \%$ to around $30 \%$ (in terms

of GDP) after the overthrow of Slobodan Milos'evic', with a probable reduced blackeconomy as well, while it has expanded and consolidated its position in Kosovo. Theconcept of a political economy here suggests that the economic sphere cannot be isolatedfrom its social and political context. The illiberal forms of economy, and the political andsocial projects they are part of, represent forms of adaptation to a marginalization andexclusion from the global political economy, where the formal economy has no place.

Although we cannot reduce causes of conflict to economic resource struggle or greed, thepolitical economy (liberal or illiberal) is integral to political projects and social relations and must, as such, be analysed as a crucial component in conflict. We should notnecessarily see illiberal economies as generators of conflict, but rather acknowledge thatthey have a central role in their dynamic, in funding agents with political agendas, and thatthey constitute the central factor and driving force in a process of social transformation. War itself is a process of social transformation, as well as of state transformation, and it isessential to acknowledge and analyse the character of the transformation and the politicaleconomy and project that emerges in the actual context of foreign intervention and aid. This is in contrast to the ideologically burdened concept of transition, where we assumeto know the direction and end state of change, and the concept of breakdown, whichsuggests that reconstruction can be approached from purely technical aspects .

\section{BIBLOGRAPHY}

\section{J. S. Sorensen}

[1] Ahmeti, S. (1994) Forms of apartheid, in: D. Janjic' \& S. Maliqi (Eds) Conflict or Dialogue (Subotica, Serbia:Open University, European Civic Centre for Conflict Resolution).

[2] Baldwin, D.A. (1985) Economic Statecraft (Princeton, NJ: Princeton University Press).

[3] Ballentine, K. (2003) Beyond greed and grievance: reconsidering the economic dynamics of armed conflict, in:K. Ballentine\& J. Sherman (Eds) Political Economy of Armed Conflict: Beyond Greed and Grievance,pp. 259-283 (Boulder, CO: Lynne Rienner Publishers).

[4] BelaKnjiga (2000) Miloševic'eveVladavine, G 17 Plus (Belgrade, Serbia: G17).

[5] Berdal, M. \& Keen, D. (1997) Violence and economic agendas in civil wars: some policy implications,Millennium, 26(3), pp. 795-818.

[6] Bogosavljevic', S. (1994) A statistical picture of Serbian-Albanian relations, in: D. Janjic' \& S. Maliqi (Eds)Conflict or Dialogue (Subotica, Serbia: Open University, European Civic Centre for Conflict Resolution).Bolzic', S. (2005) Blocked Transition and Post-socialist Transformation: Serbia in the 1990s, unpublishedmanuscript, University of Belgrade.

[7] Boutin, C. (2003) Organised Crime, Drug and Human Trafficking in Europe. Report to the Sub-Committee on Democratic Governance for the NATO Parliamentary Assembly.

[8] Bregovic', B. \&Mijatovic', B. (Eds) (2002) Corruption in Serbia (Belgrade, Serbia: Centre for Liberal Democratic Studies).

[9] Ciluffo, F. \&Salmoiraghi, G. (1999) And the Winner is ... the Albanian Mafia (Cambridge, MA: Center for Strategic International Studies, MIT).

[10] Clark, H. (2000) Civil Resistance in Kosovo (London: Pluto Press).

[11] Collier, P. (2000) Doing well out of war: an economic perspective, in: M. Berdal\& D. M. Malone (Eds) Greed and Grievance: Economic Agendas in Civil Wars, pp. 91-112 (Boulder, CO: Lynne Rienner Publishers).

[12] Dimitrijevic', V. \&Pejic', V. (1994) The Effects UN Sanctions against Yugoslavia (Serbia and Montenegro)(Belgrade: Centre for Human Rights).

[13] Dinkic', M. (2000) EkonomijaDestrukcije (Belgrade, Serbia: StuboviKulture). 
[14] Duffield, M. (1998) Post-modern conflict: warlords, post-adjustment states and private protection, Civil Wars, 1(1), pp. 65-102.

[15] Raufer, X. (2002) At the Heart of the Balkan Chaos: The Albanian Mafia. Available at http://www.xavierraufer.com/english_5php (accessed 2 February 2005).

[16] Salihu, A., Hajrullahu, M. \&Xharra, J. (2004) Radicals Test the Ground in Drenica Balkan Crisis Report no. 498,20 May 2004 (London: Institute for War \& Peace Reporting).

[17] Seper, J. (1999a) KLA finances war with heroin sales. Washington Times, 3 May. Available online at:, sarant_2/ks18kla.html">http://members.tripod.com/,sarant_2/ks18kla.html (accessed 22 February 2005).

[18] Seper, J. (1999b) Bin-Laden and the KLA. Washington Times, 4 May. Retrieved February 22, 2005, from www.diaspora-net.org/food4thought/binladen_kla.htm.

[19] Southeast European Legal Development Initiative (SELDI) (2003) Anti-corruption in Southeast Europe: First Steps and Policies (Sofia: Center for the Study of Democracy).

[20] Stanojevic', M. (1992) Regulation of industrial relations in post-selfmanagement society, in: T. Kuzmanic' \& A. Truger (Eds) Yugoslavia War (Ljubljana: Slovenia:Peace Institute).

[21] Stojic 'ic', D. (1999) How the history of Serbian culture came to life, in: R. Mrljes \&M. Kragovic' (Eds) The History of Serbian Culture, pp. 343-345 (Belgrade, Serbia: Mrljes Publishing).

[22] Thaqi, H. (2000) The KLA brought NATO to Kosova, in: J.W. Buckley (Ed.) Kosovo: Contending Voices on Balkan Interventions, pp. 282-290 (Grand Rapids, MI/Cambridge, UK: Eerdmans Publishing).

[23] Tomc, G. (1988) Classes, party elites, and ethnic groups, in: D. Rusinow (Ed.) Yugoslavia: A Fractured Federalism, pp. 58-77 (Washington, DC: The Wilson Center Press).

[24] Troebst, M. (1998) Conflict in Kosovo: Failure of Prevention? Working Paper no. 1 (Flensburg, Germany: European Centre for Minority Issues).

[25] Uzelec', A. (2005) Witness Disputes Rac ak Findings Tribunal Update no. 391, 28 January 2005 (London: Institute for War \& Peace Reporting).

[26] Vickers, M. (1998) Between Serb and Albanian: A History of Kosovo (London: Hurst \& Co).

[27] Vickers, M. \&Pettifer, J. (1997) Albania: From Anarchy to a Balkan Identity (London: Hurst \& Co).Vujovic', S. (1995) Changes in living standards and way of life among social strata, in: M. Lazic' (Ed.) Society in Crisis: Yugoslavia in the Early 1990s, pp. 85-126 (Belgrade, Serbia: FilipVis'njic'). Wallensteen, P. (1974) EkonomiskaSanktioner (Uppsala: Prisma).

[28] Xhudo, G. (1996) Men of purpose: the growth of Albanian criminal activity, Transnational Organised Crime,2(1), pp. 1-20.

[29] Yannis, A. (2003) Kosovo: the political economy of conflict and peacebuilding, in: K. Ballentine\& J. Sherman (Eds) Political Economy of Armed

[30] Duffield, M. (2000) Globalization, transborder trade, and war economies, in: M. Berdal\& D. M. Malone (Eds)Greed and Grievance: Economic Agendas in Civil Wars, pp. 69-90 (Boulder, CO: Lynne RiennerPublishers).

[31] Duffield, M. (2001) Global Governance and the New Wars: The Merging of Development and Security (London:Zed Books).

[32] Farquhar, M. (2004) Structure of KLA Explored, Tribunal Update no. 383, 26 November (London: Institute for War \& Peace Reporting).

[33] Farquhar, M. (2005) Trial Hears of KLA Tactics, Tribunal Update no 389, 14 January (London: Institute for War \& Peace Reporting).

[34] Galeotti, M. (1995) The drug threat from Eastern Europe, Jane's Intelligence Review, 1995(November),pp. 486-488.

[35] Griffiths, H. (1999) A political economy of ethnic conflict, ethno-nationalism and organised crime, Civil Wars,2(2), pp. 56-73.

[36] Hedges, C. (1999) Kosovo's next masters, in: Foreign Affairs, 78(3), pp. 24-42.

[37] Hislope, R. (2001) The Calm Before the Storm. Paper presented at the Annual Meeting of the American Political Science Association, San Fransisco, CA. 
[38] Islami, H. (1994) Demographic reality of Kosova, in: D. Janjic' \& S. Maliqi (Eds) Conflict or Dialogue, pp. 30-53(Subotica, Serbia: Open University).

[39] Janjic', D. (1994) National identity, movement and nationalism of Serbs and Albanians, in: D. Janjic' \& S. Maliqi (Eds) Conflict or Dialogue, pp. 117-176 (Subotica, Serbia: Open University, European Civic Centre for Conflict Resolution).

[40] Judah, T. (2000a) War and Revenge (Princeton, NJ: Yale University Press).

[41] Judah, T. (2000b) A history of the Kosovo Liberation Army, in: W. J. Buckley (Ed.) Kosovo: Contending Voices on Balkan Interventions (Cambridge, UK: Eerdmans Publishing).

[42] Keen, D. (2000) Incentives and disincentives for violence, in: M. Berdal\& D. M. Malone (Eds) Greed and Grievance: Economic Agendas in Civil Wars, pp. 19-42 (Boulder, CO: Lynne Rienner Publishers).

[43] Kostovic ova, D. (1997) Parallel Worlds: Response of Kosovo Albanians to Loss of Autonomy in Serbia 1986-1996 (Keele, UK: European Research Centre).

[44] Lazic', M. (1995) Transformation of the economic elite, in: M. Lazic' (Ed.) Society in Crisis: Yugoslavia in the Early 1990s, pp. 127-160 (Belgrade, Serbia: FilipVišnjic').

[45] Lazic', M. (2000) Rac 'jiHod (Belgrade, Serbia: FilipVisnjic').

[46] Lazic', M. \&Cvejic', S. (2005) Stratification changes in Serbian society: a case of blocked post-socialist transformation, in: A. Milic' (Ed.) Transformation and Strategies: Everyday Life in Serbia at the Beginning of the 3rd Millennium, pp. 35-59 (Belgrade, Serbia: Institute for Social Research).

[47] Loquai, H. (2000) Der Kosovo-Konflikt: Wege in einenvermeidbaren Krieg (Baden-Baden, Germany: NomosVerlag).

[48] Magnusson, K. (1999) Rambouilletavtalet: Texten, Fo"rhandlingarna, Bakgrunden, Current Issues 1, pp. 69-70 (Uppsala, Sweden: Centre for Multiethnic Research).

[49] Maliqi, S. (1994) Self-understanding of the Albanians in non-violence, in: D. Janjic' \& S. Maliqi (Eds) Conflict or Dialogue, pp. 237-247 (Subotica, Serbia: Open University, European Civic Centre for Conflict Resolution).

[50] Maliqi, S. (1998) Separate Worlds (Peja, Kosovo: Dukagjini Publishing).

[51] Mrks'ic', D. (1995) The dual economy and social stratification, in: M. Lazic' (Ed.) Society in Crisis, pp. 2384 (Belgrade, Serbia: FilipVisnjic).

[52] Nazi, F. (2000) Balkan diaspora 1: the American-Albanian community, in: W. J. Buckley (Ed.) Kosovo:Contending Voices on Balkan Interventions, pp. 149-152 (Cambridge, UK: Eerdmans Publishing).

[53] NGO Policy Group (2001) Third Sector in Serbia-Status and Prospects (Belgrade: Center for Development of the Non-Profit Sector).

[54] Pellna"s, B. (2004) Naivtro pa ${ }^{\circ}$ USA-mytomfolkmord [Naive belief in USA myth of genocide], DagensNyheter,February.Petkovic', M. (1998) Albanian Terrorists (Belgrade, Serbia: Kalekom).Polanyi, K. (1957) The Great Transformation (Boston: Beacon Press).

[55] Puhovski, Z. (1995) origins of the post-Yugoslav situation and the bleak prospects for civil society, in:P. Akhawan\& R. Howse (Eds) Yugoslavia-the Former and the Future (Geneva: UNRISD).Pumphrey, D. \&Pumphrey, G. (n.d.) The Racak Massacre: Casus Belli for NATO. Available online at:www.aikor.de/Artikel/gp-rac-e.htm (accessed 1 March 2005). 